\title{
Impact of Regulated Deficit Irrigation on Fruit Quality and Postharvest Storage Performance of 'Cripps Pink' Apple
}

\author{
W.S. Wan Zaliha and Zora Singh \\ Curtin Horticulture Research Laboratory, School of Agriculture and Environment, \\ Faculty of Science and Engineering, Curtin University of Technology, GPO Box U1987, \\ Perth 6845, Australia.
}

Keywords: water-deficit, anthocyanin, cold storage and controlled atmosphere

\begin{abstract}
This study aimed to develop an irrigation strategy for apples to improve fruit skin colour without adversely affecting postharvest life and quality. Regulated deficit irrigation (RDI) at different levels [(i) $100 \%$, commercial irrigation (CI) (70

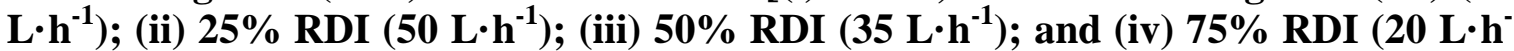
${ }^{1}$ )] was applied from 135 days after full bloom (DAFB) continuously for 72 days till harvest. RDI (75\%) significantly reduced leaf water potential as compared to CI. RDI (75\%) improved fruit skin colour via enhanced accumulation of anthocyanins, increased soluble solids concentration (SSC), fruit firmness and slightly decreased fruit diameter. The RDI fruit ( $75 \%)$ stored for 135 days at $0 \pm 0.1^{\circ} \mathrm{C}, 90 \pm 2 \% \mathrm{RH}$ remained firmer and had higher SSC compared to CI fruit. Similarly, RDI fruit (75\%) stored for 155 days in controlled atmosphere (CA) comprising of $2.7 \% \mathrm{O}_{2}+$ $1.9 \% \mathrm{CO}_{2}$ at $0^{\circ} \mathrm{C}$ had higher SSC and fruit firmness than in $\mathrm{CI}$ fruit. In conclusion, RDI (75\%) imposed at the late fruit development stage improved the fruit quality of 'Cripps Pink' apple at harvest without adversely affecting postharvest quality in cold and CA storage, and also saved the irrigation water.
\end{abstract}

\section{INTRODUCTION}

'Cripps Pink' apple [Malus sylvestris (L.) Mill var. domestica (Borkh.) Mansf.] is a commercially important apple cultivar grown in Australia. The export market demands at least $40 \%$ of fruit surface exhibiting a bright pink-red blush, 7-9 $\mathrm{kgcm}^{-2}$ of fruit firmness, 13 to $\geq 15{ }^{\circ}$ Brix SSC, size $\geq 65 \mathrm{~mm}$ and $0.7-0.9 \%$ titratable acidity (TA) (Department of Agriculture Western Australia, 2000). The application of regulated deficit irrigation (RDI) increases SSC and fruit firmness without any reduction in apple fruit size (Kilili et al., 1996b) and also saves irrigation water (Mpelasoka et al., 2001). Time of application of RDI is prerequisite to attain acceptable fruit size that has been set by the industry. Stage II of fruit development had the lowest sensitivity to the water-deficit (Boland et al., 1993). Little information is available on the effect of RDI on postharvest storage performance under cold and controlled atmosphere (CA). Water-deficit increased apple fruit firmness in cold-stored-fruit for 12 weeks (Kilili et al., 1996a) and had higher SSC following 7 days shelf life (Mpelasoka et al., 2000). Water-deficit application has been explored in various apple cultivars in various climatic conditions (Ebel et al., 1993; Kelili et al., 1996b; O’connell and Goodwin, 2007; Talluto et al., 2008). However, the information of the effects of RDI on 'Cripps Pink' apple under Western Australian conditions in the Mediterranean climate is limited. These observations prompted to investigate the effects of RDI application during stage II of fruit development of 'Cripps Pink' apple on water relation and fruit quality at harvest, following cold and CA storage. 


\section{MATERIALS AND METHODS}

The experimental trees were planted in the east-west direction (4.5 m x $2.4 \mathrm{~m}$ ) and trained in central leader system. The orchard soil is gravel in a sandy or loamy matrix. Full bloom occurred on $9^{\text {th }}$ October 2006. Treatments included were: (i) $100 \%$ CI (70 $\mathrm{L} \cdot \mathrm{h}^{-1}$, control), (ii) $25 \%$ RDI $\left(50 \mathrm{~L} \cdot \mathrm{h}^{-1}\right)$, (iii) 50\% RDI (35 L·h ${ }^{-1}$ ) and (iv) $75 \%$ RDI (20 $\mathrm{L} \cdot \mathrm{h}^{-1}$ ) with four replications. The experiment was laid out following a randomized complete block design. Two trees were treated as an experimental unit. Micro-sprinklers (Regulated Micro Sprinkler, Netafim Supernet, Tel Aviv, Israel) with a flow rate of 20-90 $\mathrm{L} \cdot \mathrm{h}^{-1}$ were used for irrigation. Irrigation treatments commenced on 135 DAFB. Leaf water potential ( $\left.\Psi_{\text {leaf }}\right)$ were recorded on 149, 156, 162, 169, 177, 183, 191, 201 DAFB. Outside the deficit periods, all the trees were irrigated the same as CI. A pressure chamber (Model 3000, Soil Moisture Equipment Corp., Santa Barbara CA, USA) was used to record $\Psi_{\text {leaf }}$ of two fully expanded mature leaves exposed to direct sunlight. Fruit diameter was recorded using a digital vernier calliper.

At harvest, various fruit quality parameters were assessed such as fruit colour, total anthocyanins concentration on the exposed (ES) and shaded (SS) sides of apple skin, firmness, TA, and SSC as according to the method described by Whale et al. (2008). Ascorbic acid (AA) concentration and total antioxidants were determined following the method outlined by Khan et al. (2008). These fruit quality parameters excluding fruit colour and total anthocyanins concentration were also assessed from cold stored $\left(0 \pm 0.1^{\circ} \mathrm{C}, 90 \pm 2 \% \mathrm{RH}\right)$ fruit for 45,90 and 135 days after harvest. Similar fruit quality parameters were assessed from fruit stored in CA $\left(2.7 \% \mathrm{O}_{2}+1.9 \% \mathrm{CO}_{2}\right.$ at $\left.0^{\circ} \mathrm{C}\right)$ storage for 155 days only, and following 14 days at ambient temperature.

The data were subjected to the analysis of variance (ANOVA) using GLM (General Linear Models) procedures and further separated by LSD for least significance at $P \leq 0.05$ (SAS Institute Inc., 1999).

\section{RESULTS}

As expected, the RDI treatment (75\%) exhibited a significant reduction of $\theta, \Psi_{\text {stem, }}$, $\Psi_{\text {leaf }}$ and $g_{s}$ as compared to CI $\left(\theta, \Psi_{\text {stem }}\right.$, and $g_{s}$ data not shown). The RDI treatment $(75 \%)$ significantly reduced $\Psi_{\text {leaf }}$ on 156,162, 169 and 177 DAFB as compared to other treatments (Fig. 1). The lowest $\Psi_{\text {leaf }}$ was recorded (-3.03 MPa) on $162 \mathrm{MPa}$ in $75 \% \mathrm{RDI}$ treatments. All RDI treatments reached normal baseline $(>-1.5 \mathrm{MPa})$ for water potential values in apple trees at the two weeks prior to commercial harvest. Final fruit size was significantly reduced $(70.22 \mathrm{~mm})$ with $75 \%$ RDI as compared to CI (Fig. 2). Fruit drop was not affected with the application of RDI treatments (data not included).

At harvest, fruit colour, total anthocyanins concentration on the both sides of apple skin, fruit firmness and SSC was significantly increased with 75\% RDI treatment as compared to CI (Table 1). The RDI treatments did not significantly affect TA. Higher concentration of AA and total antioxidants on the SS of apple skin was recorded in $75 \%$ RDI fruit as compared to other treatments (Table 1).

Fruit from $75 \%$ RDI treatment showed a significantly higher firmness and SSC following cold storage of 45, 90 and 135 days as compared to all other treatments (Table 2). All irrigation treatments showed reduced TA and increased AA concentration as cold storage period prolonged to 135 days. Fruit from all irrigation treatments exhibited higher total antioxidants on the SS during 90 days of cold storage (Table 2). However, total antioxidants decreased as cold storage prolonged to 135 days. Following 90 days cold storage, total antioxidants on the SS of fruit skin were higher in $75 \%$ RDI treatment as 
compared to CI. The higher levels of total antioxidants in the pulp were recorded in $75 \%$ RDI cold-stored-fruit during 90 days storage as compared to CI stored fruit.

Fruit firmness and SSC in CA-stored-fruit for 155 days and CA-following 14 days shelf life was significantly increased with $75 \%$ RDI treatment as compared to all other treatments (Table 3). The highest AA concentration was recorded in CA stored fruit from $75 \%$ RDI treatment as compared to CI. No significant effect of RDI treatments on AA concentrations were observed in CA-stored-fruit following 14 days shelf life. The highest total antioxidants on the ES of fruit skin in CA were recorded in fruit from $75 \%$ RDI treatment as compared to CI. Total antioxidants in CA-stored-fruit and CA-following 14 days shelf life in RDI treatment (75\%) significantly increased total antioxidants in the SS of fruit skin and pulp as compared to CI. In general, total antioxidant levels in the skin were higher than in the pulp of CA-stored-fruit and also following 14 days shelf life.

\section{DISCUSSION}

RDI treatments significantly enhanced fruit colour, SSC and fruit firmness (Table 1) with slightly reduced final fruit size (range from $3 \%$ to $8 \%$ ) as compared to CI. Improved fruit colour may be attributed to the higher concentration of total anthocyanins on the both sides of apple skin. This may be associated to the improved sunlight penetration into tree canopy and onto the fruit due to sparse leaf abscission induced by water-deficit. As reported earlier, increased anthocyanins concentration in apple skin depends on light (Saure, 1990). It may also be argued that improved fruit colour and increased concentration of anthocyanins with RDI may be ascribed to the increased levels of abscisic acid and/or ABA induced ethylene production consequently up regulated gene expression of anthocyanin biosynthesis. Increased rate of ethylene production in apple fruit due to water-deficit has been reported earlier (Ebel et al., 1993; Kilili et al., 1996a) and ethylene plays a key role in improving apple fruit colour and accumulation of anthocyanins (Saure, 1990).

Higher SSC in RDI fruit has been reported (Kilili et al., 1996b) and the increased of SSC might be due to the conversion of starch into sugars (Kramer, 1983). Firmer fruit with RDI treatments may be attributed to the reduction in cellular hydration and increased flesh compactness (Mpelasoka et al., 2000). The slight reduction observed in fruit size with RDI treatments may be due to the sources limitation (DeJong and Grossman, 1995) of photosynthesis caused by water-deficit due to lower stomatal conductance. Higher AA concentration due to water-deficit application (Table 3) have been reported, but, in different crops such as pear-jujube (Cui et al., 2008), strawberry (Liu et al., 2001) and tomato (Veit-Kohler et al., 1999). The increased of AA concentration may be associated to the higher sugars accumulation in water-deficit fruit that promotes its synthesis during fruit ripening (Veit-Kohler et al., 1999) and also might be related to its increased concentration in apple leaves under moderate water stress (Sircelj et al., 2007). The RDI treatments significantly increase total antioxidants on the SS of apple skin and pulp, possibly due to the increase of total anthocyanins concentration on the SS of apple skin and also the increased of AA concentration in the pulp.

Improved fruit firmness in cold storage subjected to water-deficit (Table 2) has been reported (Mpelasoka et al., 2000). As a prelude, the higher firmness may be ascribed to the reduction in cellular hydration. Higher SSC following cold storage may be due to the conversion of starch to sugars during ripening (Brady, 1987). SSC increased with extended storage duration. Similar effect of cold-stored-fruit in 'Braeburn' apple under water-deficit has been reported (Kilili et al., 1996a). As storage period prolonged, all RDI treatments experienced a decreased of TA. Similarly, the decreasing trends of TA was 
recorded in water-deficit 'Braeburn' apple following cold storage (Mpelasoka et al., 2000), possibly due to the consumption of malic acid as a metabolite substrate in fruit respiration (Ackermann et al., 1992). The AA concentration increased in cold-stored-fruit from $75 \%$ RDI treatment as storage duration prolonged (Table 3). In contrast, the AA concentration in apple decreased during long-term storage has been reported (Meberg et al., 2000). Possibly, the increased of AA concentration in 75\% RDI cold-stored fruit may be reflected to the increased of AA concentration at harvest and also might be due to the higher accumulation of sugars that stimulates its synthesis as explained earlier. Higher total antioxidants in cold-stored-fruit from 75\% RDI fruit were recorded (Table 2). Similarly, it has been reported that total antioxidants activity in apple skin almost double during 4 months cold storage (Leja et al., 2003). Possibly, the ethylene action during storage may have stimulated the activity of phenylalanine ammonia lyase, a key enzyme in biosynthesis of phenolic compounds consequently contributed to the increased levels of antioxidants (Leja et al., 2003).

No research work has been reported on the effect of RDI on postharvest performance of apple fruit in CA storage. Higher firmness and SSC of RDI fruit in CA and CA-following 14 days shelf life was recorded (Table 3). As explained earlier, higher firmness may be due to the cellular hydration and the increased of SSC might be ascribed to the conversion of starch into sugars. The AA concentration was significantly increased with RDI treatments in CA-stored fruit. However, fruit from all treatments in CAfollowing 14 days shelf life exhibited the decreasing trends in AA concentration. Possibly, this may be related to the increased activity of cytochrome oxidase, ascorbic acid oxidase and peroxidase enzymes (Rocha et al., 1995). In general, total antioxidants on both sides of apple skin increased with 75\% RDI treatment in CA stored-fruit and CAfollowing 14 days shelf life. As a prelude, the higher total antioxidants may be ascribed to the increased levels of enzymes activity and ethylene action may be stimulated the activity of enzymes precursor.

In conclusion, the RDI treatment (75\%) imposed at stage II of fruit development commencing from 135 DAFB continuously for 72 days till harvest effectively enhanced fruit colour development without adversely affecting fruit size and quality of 'Cripps Pink’ apple at harvest, cold and CA storage.

\section{ACKNOWLEDGEMENTS}

W.S. Wan Zaliha gratefully acknowledges University Malaysia Terengganu, Terengganu, Malaysia for financial support during her PhD research. We thank G. Casotti and Co., Karragullen, Perth Hills, Western Australia, for providing the trees and fruit used for the experiment.

\section{Literature cited}

Ackermann, J. Fisher, M. and Amado, R. 1992. Changes in sugars, acids, amino acids during ripening and storage of apples (cv. Glockenapfel). J. Agric. Food Chem. 40: 1131-1134.

Boland, A.M. Mitchell, P.D. Jerie, P.H. and Goodwin, I. 1993. The effect of regulated deficit irrigation on tree water use and growth of peach. J. Hortic. Sci. 68: 261-274.

Brady, C.J. 1987. Fruit ripening. Annu. Rev. Plant Physiol. 38: 155-178.

Cui, N. Du, T. Kang, S. Li, F. Zhang, J. Wang, M. and Li, Z. 2008. Regulate deficit irrigation improved fruit quality and water use efficiency of pear-jujube trees. Agr. Water Manage. 95:489-497. 
DeJong, T.M. and Grossman, Y.L. 1995. Quantifying sink and source limitations on dry matter partitioning of fruit growth in peach trees. Physiology Plantarum. 95:437-443.

Department of Agriculture Western Australia. 2000. Pink Lady ${ }^{\text {TM }}$. Minimum international quality specifications at destination. (Poster). Department of Agriculture Western Australia, Perth, Australia

Ebel, R.C. Proebsting, E.L. and Patterson, M.E. 1993. Regulated deficit irrigation may alter apple maturity, quality, and storage life. HortScience. 28: 141-143.

Khan, A.S. Singh., Z. Abbasi, N.A. and Swinny, E.E. 2008. Pre- or post-harvest applications of putrescine and low temperature storage affect fruit ripening and quality of 'Angelino' plum. J Sci Food Agric. 88:1686-1695.

Kilili, A.W. Behboudian, H.M. and Mills, T.M. 1996a. Postharvest performance of 'Braeburn' apples in relation to withholding of irrigation at different stages of growing season. J. Hortic Sci. 71:693-701.

Kilili, A.W. Behboudian, M.H. and Mills, T.M. 1996b. Composition and quality of 'Braeburn' apples under reduced irrigation. Scientia Horticulturae. 67:1-11.

Kramer, P.J. 1983. Water relations of plants. Academic Press, New York.

Leja, M. Mareczek, A. and Ben, J. 2003. Antioxidant properties of two apple cultivars during long-term storage. Food Chemistry. 80: 303-307.

Liu, M.C. Kojima, T. Tanaka, M. and Chen, H. 2001. Effect of soil moisture on plant growth and fruit properties of strawberry. Acta Hort. Sin. 28:307-311.

Meberg, K.R. Haffner, K. and Rosedfeld, H.J. 2000. Storage and shelf-life of apples in Norway. I. Effects of controlled atmosphere storage on 'Aroma'. Gartenbauwissenschaft. 65: 9-16.

Mpelasoka, B.S. Behboudian, H.M. Dixon, J. Neal, S.M. and Caspari, H.W. 2000. Improvement of fruit quality and storage potential of 'Braeburn' apple through deficit irrigation. J Hortic Sci Biotech. 75: 615-621.

Mpelasoka, B.S. Behboudian, H.M. and Green, S.R. 2001. Water use, yield and fruit quality of lysimeter-grown apple trees: responses to deficit irrigation and to crop load. Irrig Sci. 20:107-113.

O'connell, M.G. and Goodwin, I. 2007. Response of 'Pink Lady' to deficit irrigation and partial rootzone drying:physiology, growth, yield and fruit quality. Aust. J. Agric. Res. 58:1068-1076.

Rocha, A.M.C.N. Brochado, C.M. Kirby, R. and Morais, M.M.B. 1995. Shelf life of chilled cut orange determined by sensory quality. Food Contr. 6: 317-322.

SAS Institute Inc. 1999. SAS Procedures Guide, Version 8. Cary, NC.

Saure, M.C. 1990. External colour of anthocyanin formation in apple. Scientia Horticulturae. 42: 181-218.

Sircelj, H. Tausz, M. Grill, D. and Batic, F. 2007. Detecting different levels of drought stress in apple trees (Malus domestica Borkh.) with selected biochemical and physiological parameters. Scientia Horticulturae. 113:362-369.

Talluto, G. Farina, V. Volpe, G. and Lo Bianco, R. 2008. Effects of partial rootzone drying and rootstock vigour on growth and fruit quality of 'Pink Lady' apple trees in Mediterranean environments. Aust. J. Agric. Res. 59:785-794.

Veit-Kohler, U. Krumbein, A. and Kosegarten, H. 1999. Effect of different water supply on plant growth and fruit quality of Lycorpersicon esculentum. Soil Sci. Plant Nutr. 162:583-588.

Whale, S.K. Singh., Z. Behboudian, M.H. Janes, J. and Dhaliwal, S.S. 2008. Fruit quality in 'Cripp's Pink' apple, especially colour, as affected by preharvest sprays of aminoethoxyvinylglycine and ethephon. Scientia Horticulturae. 115: 342-351. 
Figures

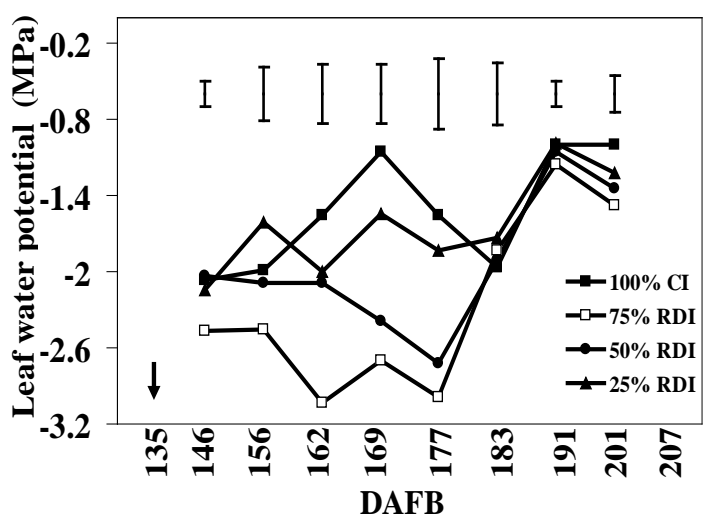

Fig. 1. Changes in leaf water potential in 'Cripps Pink' apple trees affected by different irrigation treatments during fruit development and maturation. Irrigation treatments were control $(100 \%$ CI), 25\% RDI, 50\% RDI, and 75\% RDI. Vertical bars represent $\mathrm{LSD}_{0.05}$. Arrow indicates the commencement of RDI.

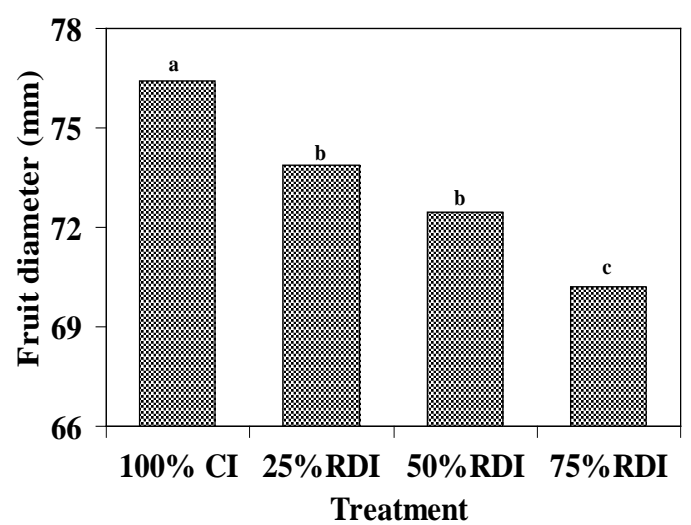

Fig. 2. Final fruit diameter in 'Cripps Pink' apple affected by different irrigation treatments. Irrigation treatments were control (100\% CI), 25\% RDI, 50\% RDI, and 75\% RDI. Means followed by the same letter are not significantly different at $\mathrm{LSD}_{0.05}$.

\section{$\underline{\text { Tables }}$}

Table 1. Effects of different RDI treatments on fruit colour, total anthocyanins concentration in the skin of 'Cripps Pink' apple skin and pulp at harvest.

\begin{tabular}{lccccc}
\hline Measurements & $100 \% \mathrm{CI}$ & $25 \% \mathrm{RDI}$ & $50 \% \mathrm{RDI}$ & $75 \% \mathrm{RDI}$ & $\mathrm{LSD}_{0.05}$ \\
\hline Fruit colour (\%) & $57 \mathrm{c}$ & $69 \mathrm{~b}$ & $72 \mathrm{ab}$ & $80 \mathrm{a}$ & 10.08 \\
Total anthocyanins $\left(\mu \mathrm{g} \cdot \mathrm{g}^{-1} \mathrm{FW}\right)$ & & & & \\
$\quad$ Skin (ES) & $142.34 \mathrm{~b}$ & $180.55 \mathrm{ab}$ & $212.91 \mathrm{a}$ & $212.14 \mathrm{a}$ & 52.39 \\
$\quad$ Skin (SS) & $28.54 \mathrm{c}$ & $54.88 \mathrm{~b}$ & $60.70 \mathrm{~b}$ & $154.02 \mathrm{a}$ & 23.92 \\
Firmness (N) & $79.50 \mathrm{~b}$ & $83.92 \mathrm{ab}$ & $85.15 \mathrm{ab}$ & $90.20 \mathrm{a}$ & 6.71 \\
SSC (\%) & $15.02 \mathrm{c}$ & $15.82 \mathrm{~b}$ & $16.22 \mathrm{~b}$ & $17.17 \mathrm{a}$ & 0.70 \\
TA (\% malic acid) & 0.79 & 0.97 & 0.77 & 0.97 & $\mathrm{NS}(0.14)$ \\
AA (mg·100g $\left.{ }^{-1} \mathrm{FW}\right)$ & $9.03 \mathrm{~b}$ & $8.50 \mathrm{~b}$ & $9.59 \mathrm{~b}$ & $12.36 \mathrm{a}$ & 2.54 \\
Total antioxidants (mM TE $\left.\cdot \mathrm{g}^{-1} \mathrm{FW}\right)$ & & & & \\
$\quad$ Skin (ES) & 20.29 & 24.99 & 21.27 & 24.36 & $\mathrm{NS}(3.75)$ \\
$\quad$ Skin (SS) & 7.09 & 6.88 & 7.82 & 13.57 & 2.11 \\
Pulp & 0.19 & 0.29 & 0.33 & 0.27 & 0.09 \\
\hline
\end{tabular}

NS=not significant and means followed by the same letter within row are not significantly different at $\mathrm{LSD}_{0.05}$. Values within brackets represent standard error of means. ES=exposed side, $\mathrm{SS}=$ shaded side. 
Table 2. Fruit firmness, soluble solids concentration, titratable acidity, ascorbic acid concentration and total antioxidants in 'Cripps Pink' apple skin and pulp affected by different RDI treatments following cold storage.

\begin{tabular}{|c|c|c|c|c|c|c|c|c|}
\hline \multirow[t]{2}{*}{ Treatment } & \multirow{2}{*}{$\begin{array}{l}\text { Storage } \\
\text { (days) }\end{array}$} & \multirow{2}{*}{$\begin{array}{l}\text { Firmness } \\
(\mathrm{N})\end{array}$} & \multirow{2}{*}{$\begin{array}{l}\text { SSC } \\
(\%)\end{array}$} & \multirow{2}{*}{$\begin{array}{c}\text { TA } \\
\text { (\%malic acid) }\end{array}$} & \multirow{2}{*}{$\begin{array}{c}\mathrm{AA} \\
\left(\mathrm{mg} \cdot 100 \mathrm{~g}^{-1} \mathrm{FW}\right)\end{array}$} & \multicolumn{3}{|c|}{ Total antioxidants $\left(\mathrm{mM}\right.$ TE$\left.\cdot \mathrm{g}^{-1} \mathrm{FW}\right)$} \\
\hline & & & & & & Skin (ES) & Skin (SS) & (pulp) \\
\hline \multirow[t]{3}{*}{$100 \% \mathrm{CI}$} & 45 & 82.07 a $\mathrm{C}$ & $15.52 \mathrm{~B}$ & $0.73 \mathrm{AB}$ & 8.45 с A & $13.63 \mathrm{~b} \mathrm{~B}$ & 8.72 b B & $0.11 \mathrm{c}$ \\
\hline & 90 & 81.92 a $\mathrm{AB}$ & $15.90 \mathrm{~B}$ & $0.70 \mathrm{~A}$ & 11.60 a $\mathrm{A}$ & $25.58 \mathrm{ab}$ & 17.75 a $C$ & 0.35 b B \\
\hline & 135 & 75.27 bB & $15.82 \mathrm{~B}$ & 0.63 & 10.51 a B & 31.62 a A & $9.54 \mathrm{~b}$ & $0.43 \mathrm{a}$ \\
\hline \multirow[t]{3}{*}{$25 \%$ RDI } & 45 & 88.17 a $\mathrm{AB}$ & 16.85 a $\mathrm{A}$ & $0.77 \mathrm{a} A$ & 6.46 с В & $26.73 \mathrm{~b} \mathrm{AB}$ & $14.83 \mathrm{AB}$ & $0.11 \mathrm{~b}$ \\
\hline & 90 & 80.22 b B & $16.48 \mathrm{~b} \mathrm{AB}$ & $0.62 \mathrm{~b} \mathrm{~B}$ & $9.46 \mathrm{~b} \mathrm{C}$ & $31.18 \mathrm{~b}$ & $19.70 \mathrm{BC}$ & 0.48 a $\mathrm{AB}$ \\
\hline & 135 & 77.57 b B & 16.08 с В & 0.56 c & 10.48 a B & 33.82 a A & 19.82 & $0.48 \mathrm{a}$ \\
\hline \multirow[t]{3}{*}{$50 \%$ RDI } & 45 & $85.62 \mathrm{BC}$ & $16.42 \mathrm{~A}$ & 0.70 а B & 6.13 b B & $33.14 \mathrm{~A}$ & $17.43 \mathrm{~A}$ & $0.11 \mathrm{~b}$ \\
\hline & 90 & $84.10 \mathrm{AB}$ & $16.72 \mathrm{~A}$ & 0.64 a $\mathrm{AB}$ & 10.46 a B & $26.50 \mathrm{~B}$ & $24.64 \mathrm{AB}$ & 0.48 а $\mathrm{AB}$ \\
\hline & 135 & $79.42 \mathrm{AB}$ & $16.42 \mathrm{AB}$ & $0.53 \mathrm{~b}$ & 11.58 a $\mathrm{A}$ & $24.79 \mathrm{~B}$ & 16.79 & 0.53 a \\
\hline \multirow[t]{3}{*}{75 \% RDI } & 45 & 91.80 a $\mathrm{A}$ & 17.17 A & 0.73 a $\mathrm{AB}$ & $9.13 \mathrm{~b} \mathrm{~A}$ & $28.09 \mathrm{~A}$ & 20.93 a A & $0.13 \mathrm{~b}$ \\
\hline & 90 & $85.60 \mathrm{~b} \mathrm{~A}$ & $17.17 \mathrm{~A}$ & $0.60 \mathrm{ab} B$ & 11.66 a A & 29.18 & 27.36 a A & 0.53 a A \\
\hline & 135 & $84.52 \mathrm{~b} \mathrm{~A}$ & $17.02 \mathrm{~A}$ & $0.49 \mathrm{~b}$ & $11.34 \mathrm{a} \mathrm{AB}$ & $24.55 \mathrm{~B}$ & $12.48 \mathrm{~b}$ & $0.57 \mathrm{a}$ \\
\hline \multicolumn{9}{|l|}{$\mathrm{LSD}_{0.05}$} \\
\hline Irrigation (I) & & 2.54 & 0.38 & 0.06 & 0.63 & NS (1.87) & 4.99 & 0.07 \\
\hline Storage (S) & & 2.03 & NS (0.11) & 0.06 & 0.56 & NS (1.74) & 4.32 & 0.06 \\
\hline $\mathrm{I} \times \mathrm{S}$ & & NS (1.53) & NS (0.23) & NS (0.04) & 1.13 & 21.40 & NS (3.01) & NS (0.04) \\
\hline
\end{tabular}


Table 3. Fruit firmness, soluble solids concentration, titratable acidity, ascorbic acid concentration and total antioxidants in 'Cripps Pink' apple affected by different RDI treatments following controlled atmosphere storage and shelf life period.

\begin{tabular}{|c|c|c|c|c|c|c|}
\hline Measurements & Storage period (days) & $100 \%$ CI & $25 \%$ RDI & $50 \%$ RDI & 75 \% RDI & $\mathrm{LSD}_{0.05}$ \\
\hline \multirow[t]{2}{*}{ Firmness (N) } & 155 days CA & $82.27 \mathrm{~b}$ & $81.77 \mathrm{~b}$ & $82.85 \mathrm{~b}$ & $89.02 \mathrm{a}$ & 5.57 \\
\hline & 155 days $\mathrm{CA}+14$ days & $84.52 \mathrm{~b}$ & $85.17 \mathrm{~b}$ & $86.25 \mathrm{~b}$ & 91.40 a & 4.16 \\
\hline \multirow[t]{2}{*}{ SSC (\%) } & 155 days CA & $15.37 \mathrm{~d}$ & $15.86 \mathrm{c}$ & $16.46 \mathrm{~b}$ & $17.17 \mathrm{a}$ & 0.39 \\
\hline & 155 days $\mathrm{CA}+14$ days & 15.57 c & $15.98 \mathrm{c}$ & $16.76 \mathrm{~b}$ & $17.28 \mathrm{a}$ & 0.44 \\
\hline \multirow[t]{2}{*}{ TA (\% malic acid) } & 155 days CA & 0.65 & 0.65 & 0.65 & 0.63 & NS (0.02) \\
\hline & 155 days $\mathrm{CA}+14$ days & 0.63 & 0.60 & 0.58 & 0.61 & NS $(0.01)$ \\
\hline \multirow[t]{2}{*}{$\mathrm{AA}\left(\mathrm{mg} \cdot 100 \mathrm{~g}^{-1} \mathrm{FW}\right)$} & 155 days CA & $10.23 \mathrm{~d}$ & $10.93 \mathrm{c}$ & $11.57 \mathrm{~b}$ & $12.57 \mathrm{a}$ & 0.50 \\
\hline & 155 days $\mathrm{CA}+14$ days & 9.89 & 8.99 & 10.18 & 9.73 & NS $(0.40)$ \\
\hline \multicolumn{7}{|c|}{ Total antioxidants (mM TE$\left.\cdot \mathrm{g}^{-1} \mathrm{FW}\right)$} \\
\hline \multirow[t]{2}{*}{ Skin (ES) } & 155 days CA & $23.16 \mathrm{~b}$ & $25.99 \mathrm{ab}$ & $24.50 \mathrm{ab}$ & $34.71 \mathrm{a}$ & 11.53 \\
\hline & 155 days $\mathrm{CA}+14$ days & 23.82 & 33.39 & 29.86 & 32.52 & NS(3.11) \\
\hline \multirow[t]{2}{*}{ Skin (SS) } & 155 days CA & $12.63 \mathrm{c}$ & $14.73 \mathrm{bc}$ & $19.45 \mathrm{ab}$ & 24.40 a & 5.07 \\
\hline & 155 days $\mathrm{CA}+14$ days & $16.52 \mathrm{~b}$ & $19.76 \mathrm{ab}$ & $17.87 \mathrm{~b}$ & 24.96 a & 6.23 \\
\hline \multirow[t]{2}{*}{ Pulp } & 155 days CA & $0.38 \mathrm{~b}$ & $0.48 \mathrm{~b}$ & $0.45 \mathrm{~b}$ & $0.62 \mathrm{a}$ & 0.10 \\
\hline & 155 days $\mathrm{CA}+14$ days & $0.52 \mathrm{~b}$ & $0.60 \mathrm{ab}$ & $0.72 \mathrm{a}$ & $0.72 \mathrm{a}$ & 0.14 \\
\hline
\end{tabular}

Means followed by the same letter within row are not significantly different at $P \leq 0.05$.Values within brackets represent standard error of means. NS=not significant $(P \leq 0.05)$. $E S=$ exposed side, $S S=$ shaded side. 